\title{
Nutritional status and food consumption of patients with Parkinson disease
}

\author{
Estado nutricional e consumo alimentar de pacientes com doença de Parkinson \\ Raissa Dias FERNANDEZ1, Jamilie Suelen dos Prazeres CAMPOS², Thais de Oliveira Carvalho Granado \\ SANTOS ${ }^{3}$
}

\begin{abstract}
Background: Parkinson's disease (PD) is a neurodegenerative disease that affects food intake as the disease progresses. The assessment of nutritional status is essential to identify early nutritional deficits. Objective: To investigate the nutritional status and food intake of patients diagnosed with PD. Methods: This was a descriptive, cross-sectional, and quantitative study. A structured questionnaire with restricted questions was applied to identify the sociodemographic profile and anthropometric measurements were taken. To evaluate the disease stage, the modified Hoehn \& Yahr scale was used. Food intake was evaluated using the Food Frequency Questionnaire (FFQ). The acquired information was organized in the Microsoft Office Excel 2010 program and statistical analysis was performed using the BioEstat 5.3 program. Results: The research was carried out with 40 patients; the majority was male (60\%), over 60 years old (52.5\%), single (55\%), with a high school degree (42.5\%), retirees (80\%), and receiving one minimum salary (42.5\%). Most were classified with eutrophic (42.5\%) and overweight (42.5\%). About food consumption, the most common foods were banana (60\%), fish (52.5\%), acerola (45\%), and orange (32\%). Among the high-risk foods, red meat (82.5\%), fried foods (30\%), heavy cream (25\%), and filled sandwich cookies (25\%) were the most common. Conclusions: Most patients had a high consumption of red meat and processed foods, with relevant consumption of some fruits and low consumption of grains and oilseeds. The disease stage was not associated with nutritional status.
\end{abstract}

Keywords: Nutritional Status; Eating; Parkinson Disease.

\section{RESUMO}

Antecedentes: A doença de Parkinson (DP) é uma doença neurodegenerativa que afeta a ingestão alimentar à medida que a doença progride. A avaliação do estado nutricional é essencial para identificar precocemente déficits nutricionais. Objetivo: Investigar o estado nutricional e o consumo alimentar de pacientes com diagnóstico de DP. Métodos: Estudo descritivo, transversal e quantitativo. Foi aplicado um questionário estruturado com questões fechadas para identificar o perfil sociodemográfico e as medidas antropométricas. Para avaliar o estágio de progressão da doença foi utilizada a escala modificada de Hoehn \& Yahr. O consumo alimentar foi avaliado por meio do Questionário de Frequência alimentar (QFA). As informações obtidas foram organizadas no programa Microsoft Office Excel 2010 e a análise estatística foi realizada por meio do programa BioEstat5.3. Resultados: Pesquisa realizada com 40 pacientes, a maioria do sexo masculino (60\%), acima de 60 anos (52,5\%), solteiros (55\%), com ensino médio (42,5\%), aposentados (80\%) e com um salário mínimo (42,5\%). Foram classificados com eutrofia (42,5\%) e com excesso de peso (42,5\%). Com relação ao consumo alimentar, destacou-se o consumo de banana (60\%), peixe (52,5\%), acerola (45\%) e a laranja (32\%). Entre os alimentos de risco destacou-se a carne vermelha (82,5\%), fritura (30\%), creme de leite (25\%), e biscoito recheado (25\%). Conclusões: A maioria dos pacientes apresentou consumo elevado de carne vermelha e alimentos processados, com consumo relevante de algumas frutas e baixo consumo de grãos e oleaginosas. 0 estágio de progressão da doença não teve associação com o estado nutricional.

Palavras-chave: Estado Nutricional; Ingestão de Alimentos; Doença de Parkinson.

\section{INTRODUCTION}

Parkinson's disease (PD) was described for the first time in 1817 by the English physician James Parkinson, who named the condition "paralysis agitans" ${ }^{1}$. It is a degenerative disease that affects the central nervous system (CNS) and results in the death of dopamine-producing neurons in the substantia nigra $^{2}$.

Motor symptoms include tremors at rest, stiffness, bradykinesia, postural instability, and locomotion problems.

\footnotetext{
'Universidade Federal do Pará, Programa de Residência em Neurologia do Centro Universitário do Estado do Pará, Belém PA, Brasil.

${ }^{2}$ Universidade Federal do Pará, Centro Universitario do Estado do Pará, Belém PA, Brasil.

${ }^{3}$ Fundação Santa Casa de Misericórdia do Pará, Programa de Pós Graduação em Gestão e Saúde na Amazônia, Belém PA, Brasil.

RDF (D) https://orcid.org/0000-0001-6363-7939; JSPC (1) https://orcid.org/0000-0003-1996-294X; TOCGS (D) https://orcid.org/0000-0001-9496-4561

Correspondence: Raissa Dias Fernandez; Email: raissadias_fernandez@hotmail.com.

Conflict of interest: The authors have no conflicts of interest to declare.

Authors' contributions: RDF: preparation, acquisition, study design, data collection, data analysis, writing and final review; JSPC: study design, analysis of statistical data and final review; TOCGS: study design, acquisition and final review.

Received on February 11, 2020; Received in its final form on September 29, 2020; Accepted on October 29, 2020.
} 
These symptoms allow the classification of the disease stage, which is essential to the identification of the needs and the definition of the approach ${ }^{3}$ to be used. Other clinical manifestations may occur, such as melancholy, problems with selfesteem, lack of appetite, dysphagia, and eating difficulty ${ }^{4,5}$.

As the disease progresses, food intake is affected and nutritional complications may arise, causing weight loss and, in more severe cases, malnutrition ${ }^{6}$. Among the causes of weight loss, the abnormal and involuntary movements such as rest tremors and dyskinesias result in an increased energy output and hypercatobolism ${ }^{7}$. Dyskinesias can even directly influence the quality of life of the patients, as they can negatively interfere in the physiological process of swallowing, making food intake even more difficult ${ }^{8}$.

Due to the clinical symptoms associated with the pathology, food has an influence on certain aspects of the disease, and a proper nutrition helps in weight recovery and maintenance, promoting well-being and preventing complications associated with the evolution of $\mathrm{PD}^{5}$.

A study by Mischley ${ }^{9}$ found that the consumption of processed and ultra-processed foods by Parkinson's patients such as ice cream, heavy cream, sodas, and canned fruits and vegetables was associated with higher rates of PD progression. On the other hand, the food items of the Mediterranean diet have been associated with a reduction in the incidence and progression of $\mathrm{PD}^{9}$.

The Mediterranean diet is based on a healthy and balanced diet composed of grains, preferably whole, with intact fibers, different types of vegetables, fruits, which are present in most meals, and high-water intake. In addition, this type of diet includes fresh and minimally processed foods, rich in nutrients, antioxidants, and protective substances ${ }^{10}$.

Through food consumption and nutritional status assessment, it is possible to identify nutritional deficits early ${ }^{11}$. Several methods can be used to assess the nutritional status of adults and the elderly, and the ones worth mentioning are: body mass index (BMI), calf circumference (CP), and the Mini Nutritional Assessment (MAN), which associated with the Food Frequency Questionnaire (FFQ), offer important information for the global nutritional status ${ }^{11}$.

The aims of this study were to assess the nutritional status and food consumption of patients diagnosed with PD, identify the sociodemographic profile, and evaluate the association between stage of disease and nutritional status.

\section{METHODS}

This was a descriptive, quantitative, cross-sectional study carried out with 40 patients attending the Neurology Outpatient Clinic of Hospital Ophir Loyola from June to September of 2019. The sample was defined by convenience, considering the flow of patients treated at the referred outpatient clinic. Only those who signed the consent form participated in the study. The research was approved by the Research Ethics Committee of the Centro Universitario do Estado do Pará (CESUPA) and the Research Ethics Committee of Hospital Ophir Loyola, complying with the legal requirements of the National Health Council.

Female or male patients, aged over 18 years and undergoing PD treatment, were included in the study. Two consent forms were available: one for the participants able to answer the questionnaires by themselves and another for the companions or legal guardians that would fill the questionnaires in case the patient could not do it.

A structured questionnaire with restricted questions was applied to the research participants for the collection of patient information (age and date of birth), sociodemographic data (marital status, education level, and average family income), and anthropometric measures (weight, height, calf circumference, knee height, and BMI).

To evaluate the PD stage, the modified Hoehn \& Yahr scale (HY - Degree of Disability Scale) was used, which assesses how disable individuals with PD are. The signs and symptoms were observed at the time of the data collection, and the scale was applied by the researchers, who were duly trained by a neurologist.

$\mathrm{PD}$ has 5 stages and patients were grouped into stages 1-3 and 4-5. Stage 1 is the initial phase of the disease, stage 2 is characterized by bilateral symptoms, stage 3 , by moderate postural instability, stage 4 , severe postural instability, and stage 5 , total physical impairment ${ }^{12}$. The association of stage with nutritional status was later verified.

The assessment of nutritional status was carried out by two methods: the Anthropometric Assessment for adults and the Mini Nutritional Assessment (MAN) exclusive for the elderly. Weight was measured on an electronic digital scale and height, by a 200-cm portable stadiometer, with $1 \mathrm{~cm}$ accuracy.

After measuring weight and height, the body mass index of the patients $\left(\mathrm{BMI}=\right.$ weight $/$ height $\left.^{2}\right)$ was calculated. The BMI classification was performed according to the recommendations by the World Health Organization (WHO) ${ }^{13}$. In order to measure the brachial circumference, an inelastic measuring tape was used. When the patient was unable to walk, anthropometric measurements were estimated according to the equations of the Chumlea ${ }^{14}$ method.

Food consumption was assessed by the adapted Food Frequency Questionnaire (FFQ $)^{8}$. The frequency of consumption categories included: $1 \mathrm{x}$ a day, $2 \mathrm{x}$ or more per day, 4 to $6 \mathrm{x}$ per week, 2 to $3 x$ per week, $1 x$ per week, $1 x$ per month, $2 \mathrm{x}$ or more a month, and rarely or never.

The FFQ was divided into two categories. The first one included foods considered to be protective, associated with reduced incidence rates and progression of the disease, such as omega-3, zinc, magnesium, iron, vitamin $\mathrm{A}$, vitamin $\mathrm{C}$, and vitamin B6 and B12 (micronutrients considered relevant for cognition and neurological health of individuals with $\mathrm{PD}^{15}$ ). 
The second category included high-risk foods, with high levels of fats and sugars, which promote high metabolic demand of neurons and make cells more susceptible to oxidative damage, with a negative impact in neurodegeneration ${ }^{9,15}$.

The protective foods category included: pineapple, kiwi, banana, watermelon, orange, tangerine, acerola, chia seeds, linseed, nuts, chestnut, oats, whole wheat bread, brown rice, olive oil, and fish. The high-risk category included: soda, diet soda, ice cream, heavy cream, yellow cheese, canned foods, red meat, pork, juice boxes, filled sandwich cookies, and fried foods.

For the analysis of the food profile, the methodology adapted from the Sichieri study ${ }^{16}$ was used, where the level of consumption was obtained from the transformation of the frequencies informed into fractions of the daily frequency. Then, the weighted average frequency of consumption was calculated and the following cut-off points were applied to categorize the level of consumption: $<0.33$ for low consumption; $>0.33$ and $<0.66$ for average consumption; and $>0.66$ for high consumption.

The information gathered with the questionnaires was organized in a database in the Microsoft Office Excel 2010 program. For the statistical analysis of the data, the program BioEstat version 5.3 was used, with the application of the $\mathrm{G}$ test to verify possible associations between the variables related to nutritional status, food consumption, and symptoms of disease progression, considering a significance level of 0.05 .

\section{RESULTS}

Forty PD patients were evaluated, the majority of whom were male over 60 years old, single, with high school education, retired, and with an income of up to one minimum wage (Table 1).

Table 2 shows the results of the nutritional status according to BMI and the stages of the disease. There was a higher prevalence of individuals classified as eutrophic and overweight. Most patients were in stage 1 of the disease. Therefore, no association between nutritional status and disease progression was found ( $p=0.6058)$.
Table 1. Characterization of the sociodemographic profile of patients with Parkinson's disease treated at a Neurology Reference Center.

\begin{tabular}{|c|c|c|}
\hline Sociodemographic profile & $\mathrm{N}$ & $\%$ \\
\hline \multicolumn{3}{|l|}{ Sex } \\
\hline Female & 16 & 40.0 \\
\hline Male & 24 & 60.0 \\
\hline \multicolumn{3}{|l|}{ Age } \\
\hline 40 to 50 years & 4 & 10.0 \\
\hline$>50$ to 60 years & 15 & 37.5 \\
\hline$>60$ years & 21 & 52.5 \\
\hline \multicolumn{3}{|l|}{ Marital status } \\
\hline Single & 22 & 55.0 \\
\hline Married & 10 & 25.0 \\
\hline Widower & 3 & 7.5 \\
\hline Common law partners & 4 & 10.0 \\
\hline Divorced & 1 & 2.5 \\
\hline \multicolumn{3}{|l|}{ Educational level } \\
\hline Illiterate & 5 & 12.5 \\
\hline Elementary school & 14 & 35.0 \\
\hline High school & 17 & 42.5 \\
\hline University education & 4 & 10.0 \\
\hline \multicolumn{3}{|l|}{ Occupation } \\
\hline Retired & 32 & 80.0 \\
\hline Working & 6 & 15.0 \\
\hline From Home & 2 & 5.0 \\
\hline \multicolumn{3}{|l|}{ Family income } \\
\hline Until 1 minimum wage (MS) & 17 & 42.5 \\
\hline$>1 \mathrm{MS}$ to3 MS & 15 & 37.5 \\
\hline$>3 \mathrm{MS}$ to $6 \mathrm{MS}$ & 6 & 15.0 \\
\hline$>6 \mathrm{MS}$ & 2 & 5.0 \\
\hline
\end{tabular}

Source: Field Research 2019.

Table 3 shows the results for the FFQ. The protective foods most commonly consumed were banana and fish. Among the high-risk foods, red meat stood out.

Table 2. Nutritional status and stages of disease progression according to the modified scale of Hoehn \& Yahr of Patients with Parkinson's Disease treated at a Neurology Reference Center.

\begin{tabular}{|c|c|c|c|c|c|c|c|c|c|}
\hline \multirow[b]{2}{*}{ Stages } & \multicolumn{2}{|c|}{ Under weight } & \multicolumn{2}{|c|}{ Eutrophy } & \multicolumn{2}{|c|}{ Overweight } & \multicolumn{2}{|c|}{ Total } & \multirow[t]{2}{*}{ Value-p* } \\
\hline & $\mathrm{N}$ & $\%$ & $\mathrm{~N}$ & $\%$ & $\mathrm{~N}$ & $\%$ & $\mathrm{~N}$ & $\%$ & \\
\hline Stage 1-3 & 4 & 12.5 & 14 & 43.8 & 14 & 43.8 & 32 & 100 & 0.6058 \\
\hline Stage 4-5 & 2 & 25.0 & 3 & 37.5 & 3 & 37.5 & 8 & 100 & \\
\hline
\end{tabular}

*G test.

Source: Field Research 2019. 
Table 3. Food consumption according to FFQ of patients with Parkinson's disease treated at a Neurology Reference Center.

\begin{tabular}{|c|c|c|c|c|c|c|c|c|}
\hline \multirow[b]{2}{*}{ Protective foods } & \multicolumn{2}{|c|}{ Daily } & \multicolumn{2}{|c|}{ Weekly } & \multicolumn{2}{|c|}{ Monthly } & \multicolumn{2}{|c|}{ Rare / Never } \\
\hline & $\mathrm{N}$ & $\%$ & $\mathrm{~N}$ & $\%$ & $\mathrm{~N}$ & $\%$ & $\mathrm{~N}$ & $\%$ \\
\hline Pineapple & 0 & 0.0 & 11 & 27.5 & 13 & 32.5 & 16 & 40.0 \\
\hline Kiwi & 0 & 0.0 & 0 & 0.0 & 3 & 7.5 & 37 & 92.5 \\
\hline Banana & 11 & 27.5 & 24 & 60.0 & 4 & 10.0 & 1 & 2.5 \\
\hline Watermelon & 0 & 0.0 & 15 & 37.5 & 9 & 22.5 & 16 & 40.0 \\
\hline Orange & 1 & 2.5 & 13 & 32.5 & 15 & 37.5 & 11 & 27.5 \\
\hline Tangerine & 0 & 0.0 & 6 & 15.0 & 20 & 50.0 & 14 & 35.0 \\
\hline Acerola & 4 & 10.0 & 18 & 45.0 & 6 & 15.0 & 12 & 30.0 \\
\hline Chiaseeds & 0 & 0.0 & 0 & 0.0 & 1 & 2.5 & 39 & 97.5 \\
\hline Oats & 11 & 27.5 & 5 & 12.5 & 4 & 10.0 & 20 & 50.0 \\
\hline Linseed & 1 & 2.5 & 0 & 0.0 & 1 & 2.5 & 38 & 95.0 \\
\hline Nuts & 1 & 2.5 & 0 & 0.0 & 2 & 5.0 & 37 & 92.5 \\
\hline Chestnuts & 2 & 5.0 & 1 & 2.5 & 13 & 32.5 & 24 & 60.0 \\
\hline Olive oil & 12 & 30.0 & 10 & 25.0 & 2 & 5.0 & 16 & 40.0 \\
\hline Brown bread & 7 & 17.5 & 3 & 7.5 & 3 & 7.5 & 27 & 67.5 \\
\hline Brown rice & 5 & 12.5 & 1 & 2.5 & 1 & 2.5 & 33 & 82.5 \\
\hline Fish & 2 & 5.0 & 21 & 52.5 & 14 & 35.0 & 3 & 7.5 \\
\hline \multicolumn{9}{|l|}{ Risk foods } \\
\hline Soda & 6 & 15.0 & 7 & 17.5 & 9 & 22.5 & 18 & 45.0 \\
\hline Diet soda & 0 & 0.0 & 1 & 2.5 & 1 & 2.5 & 38 & 95.0 \\
\hline Ice cream & 0 & 0.0 & 1 & 2.5 & 15 & 37.5 & 24 & 60.0 \\
\hline Heavy cream & 0 & 0.0 & 10 & 25.0 & 5 & 12.5 & 25 & 62.5 \\
\hline Yellow cheese & 1 & 2.5 & 9 & 22.5 & 3 & 7.5 & 27 & 67.5 \\
\hline Canned food & 3 & 7.5 & 6 & 15.0 & 7 & 17.5 & 24 & 60.0 \\
\hline Read meat & 2 & 5.0 & 33 & 82.5 & 1 & 2.5 & 4 & 10.0 \\
\hline Pork & 0 & 0.0 & 4 & 10.0 & 6 & 15.0 & 30 & 75.0 \\
\hline Juice box & 1 & 2.5 & 5 & 12.5 & 3 & 7.5 & 31 & 77.5 \\
\hline Stuffed biscuits & 0 & 0.0 & 10 & 25.0 & 6 & 15.0 & 24 & 60.0 \\
\hline Fried food & 6 & 15.0 & 12 & 30.0 & 10 & 25.0 & 12 & 30.0 \\
\hline
\end{tabular}

Source: Field Research 2019.

\section{DISCUSSION}

In general, PD incidence does not vary with race, social class, or gender, but studies have found evidence that there is a higher prevalence in $\operatorname{men}^{7,513}$. In this study, the population was mainly composed of males (60\%), similar to the findings by Carmo and Freire ${ }^{7}$, where $57.5 \%$ of the patients were male and $52.5 \%$ were over 60 years old.

The occupation results were related to the age of the patients, since the majority reported being retired, corroborating the findings by Silvas et $\mathrm{a}^{17}$ research, in which the majority the participants were also retired. As a degenerative disease, PD can cause disability 10 to 15 years after diagnosis, resulting in a high social and financial impact ${ }^{18}$.

In this study, a higher prevalence of eutrophic individuals was found, followed by overweight. Similar result were found in the study by Moraes et $\mathrm{al}^{5}$, in which $81.2 \%$ of the sample were eutrophic or overweight, and in the study by Guerdão et $\mathrm{al}^{3}$, where $70 \%$ were overweight and obese.

Regarding the nutritional status and the stage of disease, most of the participants classified as eutrophic and overweight were in stage 1 , which possibly occurred because they were patients treated at an outpatient basis. Furthermore, in this sample, there was no significant association between nutritional status and disease stage. The study by Guerdão et $\mathrm{al}^{3}$ also found no significant association between nutritional status and disease stage.

The most commonly consumed protective foods were banana, followed by fish, acerola, watermelon, and orange. Banana is a source of vitamin B6 that, associated with vitamin $\mathrm{B} 12$, can act in the homocysteine purification cycle $^{19}$. Homocysteine is an amino acid that at high plasma 
concentrations can cause brain injury associated with neuropsychiatric disorders $^{19,20}$.

The biochemical alteration caused by homocysteine accumulation may cause increased oxidative stress, a factor related to brain aging and neural damage. This amino acid is associated with prolonged use of levodopa that can generate hyperhomocysteinemia, promoting the development of vascular complications, which predispose to CNS disorders ${ }^{19,20}$.

The high fish consumption may be associated with the fact that the northern region population has a preference for fish in their meals, and fishing has become one of the main extractive activities, supplying urban and riverside $\operatorname{areas}^{21}$. Fish is rich in omega-3, which acts as an anti-inflammatory neuroprotector, essential for the motor and cognitive functions usually affected in PD, with an important role in reducing symptoms ${ }^{22}$.

The fruits consumed often by patients in our study, such as acerola and oranges, are rich in antioxidant vitamins and protective substances such as omega-3, which together act to prevent cell destruction from the oxidation of cell membranes. Among the metabolic changes, oxidative damage is an important predisposing factor for PD, since neurons are especially vulnerable to damage from free radicals ${ }^{19}$.

In contrast, many other foods that are sources of antioxidant vitamins, omega-3, selenium, and fiber were reported as consumed rarely or never, including chia seeds, linseed, chestnuts, kiwi, and brown rice. This result is similar to the study by Moraes et $\mathrm{al}^{5}$, in which patients had low consumption of whole foods and oilseeds.

A low consumption of legumes, roots, tubers, fruits, and vegetables may contribute even more with the progress of the disease $^{23}$. However, among many factors that influence food choices, a study ${ }^{24}$ mentions financial problems as the main factor in food purchase decisions. Economic restrictions on the purchase of food lead to diets with low consumption of fruits and vegetables.

A study by Borges ${ }^{25}$ linked the quality of the diet with social class, and stated that the health status of individuals belonging to lower social classes would be worse than the status of those from higher social classes. The food consumption of the low-income Brazilian population is characterized by the large amount of grains, oils and fats, sugars, high fat meats, and processed foods, mostly high energy density foods, and in this study most of the patients evaluated reported having an income of one minimum wage.
As for high-risk foods, the weekly consumption of red meat, fried foods, heavy cream, filled cookies, and yellow cheese was high, followed by the monthly consumption of ice cream. Recent research suggests that the meat consumed in the Western diet has a high fat content. In addition, a high intake of meat has been linked to the incidence and progression of $\mathrm{PD}$, as it would be associated with the accumulation of alpha-synuclein in the enteric nervous system, through the activation of immune cells and the cross-reactivity between antigens. The accumulation of alpha-synuclein in the form of intracellular filamentous aggregates is one of the pathological features of neurodegenerative diseases ${ }^{9,26}$.

Another relevant aspect about dietetic protein is that the amino acids from animal proteins and the levodopa drug compete for the same active transport mechanism in the gastrointestinal tract and blood-brain barrier, thus causing decreased absorption of the drug and affect its therapeutic action $^{27}$.

Other highly consumed items were fried foods in general and dairy products. It is known that lipid peroxidation is involved in the pathogenesis of many neurodegenerative disorders ${ }^{9}$. The study carried out by Dalbeth et $\mathrm{al}^{28}$ mentions some mechanisms responsible for the association of dairy products with progression of PD. Intake of dairy products reduces uric acid in the CNS (low uric acid levels are associated with a higher incidence of PD). In addition, dairy products can contain pesticide residues that are neurotoxic and have pro-oxidant properties.

In the present study, most of the participants were elderly, eutrophic, males with an income around one minimum wage. Most reported a high consumption of red meat and processed foods. It is worth noticing that the financial condition of patients may have made it difficult to include protective foods into the diet.

Regarding the limitations of the study, the sample size was restricted, because the data collection occurred according to the flow of care in the institution where the research was conducted, which affected the number of participants. In addition, the scarcity of studies with this type of analysis also limited the comparison of results. More studies should be conducted with a higher number of interviewees and in different groups, in order to obtain more information about the relationship between diet and PD.

\section{REFERENCES}

1. Bravo PAF, Nassif MC. Doença de Parkinson: terapêutica atual e avançada. Infarma. 2006;18(9-10):25-9.

Souza CFM, Almeida HCP, Sousa JB, Costa PH, Silveira YSS, Bezerra JC. A Doença de Parkinson e o processo de envelhecimento motor: uma revisão de literatura. Rev Neurocienc. 2011;19(4):718-23.

3.

Guerdão MDQP, Silva SMCA, Silva MLN, Roediger MA. Estado nutricional e ingestão proteica de idosos com Doença de Parkinson. REAS. 2019 Jan 31;11(6):e219. https://doi.org/10.25248/reas. e219.2019

4. Bigal A, Harumi D, Luz M, De Luccia G, Bilton T. Disfagia do idoso: estudo videofluoroscópico de idosos com e sem Doença de Parkinson. Distúrb Comum. 2007;19(2):213-23. 
5. Morais MB, Fracasso BM, Busnello FM, Mancopes R, Rabito El. Doença de Parkinson em idosos: ingestão alimentar e estado nutricional. Rev Bras Geriatr Gerontol. 2013;16(3)503-11.

6. Rodrigues MA, Cechella M. Alimentação na Doença de Parkinson. Disciplinarium Scientia. 2002;3(1):13-22.

7. Carmo TPS, Ferreira CCD. Avaliação nutricional e uso da Levodopa em pacientes com Doença de Parkinson. Rev Bras Geriatr Gerontol. 2016 Mar-Apr;19(2):223-34. https://doi.org/10.1590/180998232016019.150141

8. Mancopes R, Busanello-Stella AR, Finger LS, Neu AP, Pacheco AB, Torriani MS. Influência da Levodopa sobre a fase oral da deglutição em pacientes com Doença de Parkinson. Rev CEFAC. 2013 Jun;15(3):707-12. https://doi.org/10.1590/S151618462013005000023

9. Mischley LK, Lau RC, Bennett RD. Role of diet and nutritiona supplements in Parkinson's Disease progression. Oxid Med Cell Longev. 2017;2017:6405278. https://doi.org/10.1155/2017/6405278

10. Bonito J. A dieta mediterrânica na prevenção de doenças da contemporaneidade: uma revisão bibliográfica. REBES. 2016 JanMar;6(1):27-35. https://doi.org/10.18378/rebes.v6i1.3907

11. da Paz RC, Fazzio DMG, dos Santo ALB. Avaliação nutricional em idosos institucionalizados. Revisa. 2012 Jan-Jun;1(1):9-18.

12. Ferreira VF, Prado ALC, Cielo CA, Busanello AR. A relação da postura corporal com a prosódia na Doença de Parkinson: estudo de caso. Rev CEFAC. 2007 Jul-Sep;9(3):319-29.

13. World Health Organization. Physical status: the use of and interpretation of anthropometry, report of a WHO expert committee. Technical Report series 854. Geneva: OMS; 1995. 463 p.

14. Chumlea WC, Guo S, Roche AF, Steinbaugh ML. Prediction of body weight for the nonambulatory elderly from anthropometry. J Am Diet Assoc. 1988 May;88(5):564-8.

15. Seidl SE, Santiago JA, Bilyk H, Potashkin JA. The emerging role of nutrition in Parkinson's disease. Front Aging Neurosci. 2014 Mar 7;6:36. https://doi.org/10.3389/fnagi.2014.00036

16. Sichieri R. Avaliação do consumo alimentar e do consumo de energia. In: Sichieri R., org. Epidemiologia da obesidade. 1st ed. Rio de Janeiro (RJ): Eduerj; 1998. p. 65-88.

17. da Silva PCS, Fernandes ACBC, Terra FS. Avaliação da depressão e da capacidade funcional em idosos com Doença de Parkinson. Rev
Enferm UFPE online. 2014 Jul;8(7):1920-7. https://doi.org/10.5205/ reuol.5963-51246-1-RV.0807201413

18. Ministério da Saúde. Portaria n 228, de 10 de maio de 2010. Protocolos clínicos e diretrizes terapêuticas: Doença de Parkinson. Brasília (DF): Secretaria de Atenção à Saúde; 2010.

19. Dantas AMC, Frank AA, Soares EA. Vitaminas antioxidantes na Doença de Parkinson. Rev Bras Geriatr Gerontol. 2008 JanApr;11(1):105-16. https://doi.org/10.1590/1809-9823.2008.110110

20. Vilaça CO, de Freitas MRG, do Nascimento OJM, Orsini M, Leite MAA, de Souza JA. Metabolismo da homocisteína em doenças neurológicas. Rev Bras Neurol. 2015 Jul-Sep;51(3):73-8.

21. Lopes IG, de Oliveira RG, Ramos FM. Perfil do consumo de peixes pela população brasileira. Biota Amazônia. 2016;6(2):62-5. https://doi. org/10.18561/2179-5746/biotaamazonia.v6n2p62-65

22. Correia A, Nobre M, Pires MN, Lopes JP, Lucetti DL, Cristina E, et al. Omega-3 fatty acids: neuroprotective, antioxidant and antilnflammatory effects in a model of Parkinson's Disease. Ann Neurodegener Dis. 2016;1(4):1018.

23. Lopez AM, Weintraub D, Claassen DO. Impulse control disorders and related complications of Parkinson's Disease therapy. Semin Neurol. 2017 Apr;37(2):186-92. https://doi.org/10.1055/s-0037-1601887

24. Claro RM, do Carmo HCE, Machado FMS, Monteiro CA. Renda, preço dos alimentos e participação de frutas e hortaliças na dieta. Rev Saúde Pública. 2007 Aug;41(4):557-64. https://doi.org/10.1590/ S0034-89102007000400009

25. Borges CA, Claro RM, Martins APB, Villar BS. Quanto custa para as famílias de baixa renda obterem uma dieta saudável no Brasil? Cad Saúde Pública. 2015 Jan;31(1):137-48.

26. Perfeito R, Rego AC. Papel da Alfa-sinucleína e da disfunção mitocondrial associada à Doença de Parkinson. Rev Neurocienc. 2012;20(2):273-84. https://doi.org/10.34024/rnc.2012.v20.8280

27. Fracasso BM, Morais MB, Gomez R, Hilbig A, Rabito El. Protein intake and the use of levodopa in patients with Parkinson's disease. Rev Chil Nutr. 2013 Jun;40(2):102-6. https://doi.org/10.4067/S071775182013000200001

28. Dalbeth N, Ames R, Gamble GD, Horne A, Wong S, Kuhn-Sherlock B, et al. Effects of skim milk powder enriched with glycomacropeptide and G600 milk fat extract on frequency of gout flares: a proof-of-concept randomized controlled trial. Ann Rheum Dis. 2012 Jun;71(6):929-34. https://doi.org/10.1136/annrheumdis-2011-200156 